\title{
A systematic review of symptomatic outcomes used in oesophagitis drug therapy trials
}

\author{
N Sharma, C Donnellan, C Preston, B Delaney, G Duckett, P Moayyedi
}

Gut 2004;53(Suppl IV):iv58-iv65. doi: 10.1136/gut.2003.034371

Symptoms are an important outcome for measurement in clinical trials into gastro-oesophageal reflux disease, but the optimal approach to symptom assessment has not been formally evaluated. The authors conducted a systematic review to assess how reflux symptoms have been evaluated and how well these correlate with oesophagitis healing and relapse.

See end of article for authors' affiliations .....................

Correspondence to: Professor P Moayyedi, Gastroenterology Division, McMaster University-HSC 4W8, 1200 Main Street West, Hamilton, Ontario, Canada L8N 3ZZ5; evans|@mcmaster.ca

\section{SUMMARY}

The Cochrane Controlled Trials Register, MEDLINE, EMBASE, and CINAHL electronic databases were searched for randomised controlled trials of drug therapies in reflux oesophagitis. Experts in the field and pharmaceutical companies were contacted for information on any unpublished eligible trials. Predefined eligibility and validity criteria determined inclusion the symptom assessment methodologies used, including scales, methods of data collection, duration of assessments, individual and global symptoms assessed, whether reduction or absence of symptoms was the main outcome measure, types of symptoms assessed, and frequency and severity of symptoms. The proportions of patients with a successful outcome according to these different symptom measures were compared with the proportions of patients in whom oesophagitis had healed (initial therapy studies) or in whom oesophagitis had not relapsed (maintenance studies). The results are primarily evaluated in the form of L'Abbé plots.

Data were extractable from 140 eligible trials. Absent or minimal symptoms correlated well with oesophagitis healing and absence during maintenance therapy, whereas symptom reduction overestimated treatment effects. Trials that measured symptoms over a stated time period showed better correlation of symptom status with oesophagitis healing and relapse than those that did not define the time period. Heartburn was the most useful symptom for prediction of oesophagitis healing but the L'Abbé plots suggested additional information may also be obtained from regurgitation and dysphagia.

Published trials of drug therapy of reflux oesophagitis use a wide range of symptom outcome measures. Comparisons with oesophagitis status suggest that some of the measures used are suboptimal. Methodologies used for acquisition of symptom data are also diverse, and of studies in this analysis. Data were extracted on frequently inconsistent with general principles derived from formal research into the processes of symptom evaluation.

\section{INTRODUCTION}

Trials that evaluate the efficacy of drug treatments in reflux oesophagitis patients use healing of oesophagitis as the main outcome measure. Although many oesophagitis classifications exist, there has been progress recently with critical evaluation and standardisation of the severity grading of oesophagitis so that results from different studies can be compared. ${ }^{1}$ More recently, the major impacts of reflux induced symptoms have been better recognised, and, indeed, these are the primary outcome measures for trials on endoscopy negative reflux disease. ${ }^{2}$ Unfortunately, there have been no attempts to optimise, and then to standardise methods of symptom evaluation in the assessment of gastrooesophageal reflux disease (GORD). It is, therefore, difficult to compare studies. Trials have measured single symptoms, such as heartburn, or have evaluated global upper gastrointestinal symptoms. Treatment success has been variably defined as a subjective reduction or a complete absence of symptoms. There has also been variation in the time periods over which symptoms have been assessed, the scales used, and whether information was obtained from diary cards, self administered questionnaires, or investigator interview. These issues are pertinent to trials that assess the efficacy of therapy for initial treatment of GORD and for subsequent maintenance of patients in remission.

We are currently conducting Cochrane systematic reviews ${ }^{3}{ }^{4}$ into the efficacy of medical therapies for the treatment of GORD. The primary aim of these reviews is to determine the most efficacious therapy for reflux disease. In this study, we have used these databases to gain a comprehensive overview of the outcome measures that have been used in these trials and to examine which of these appears to be the most appropriate. For this, we have compared the outcomes of the different methods of symptom assessment with the reference outcome of healing and prevention of relapse of oesophagitis, the most objective end point of successful treatment of GORD that is available.

Abbreviations: GORD, gastro-oesophageal reflux disease; PGWBI, psychological general well being index; SF-36, short form 36 


\section{METHODS}

This study used data collected from two systematic reviews of short term therapy for reflux oesophagitis ${ }^{3}$ and of long term maintenance therapy in oesophagitis patients. ${ }^{4}$ Though this latter review ${ }^{4}$ also collates data from endoscopy negative reflux disease patients, data from this patient group have not been used in this analysis.

Randomised controlled trials were identified from the Cochrane Controlled Trials Register, MEDLINE (1966-2000), EMBASE (1988-2000), and CINAHL (1982-2000). The search terms used have been outlined elsewhere. ${ }^{3}$

Papers identified by the search strategy were reviewed for eligibility (see below) by two researchers using predefined criteria. The researchers' initial judgements were blinded to the conclusions on eligibility reached by their colleague. Any discrepancies between the two researchers were then resolved by discussion of the paper. Eligible trials underwent data extraction using a predesigned data extraction form, which was checked by a second reviewer.

\section{Short term trials}

Initial therapy trials on patients with oesophagitis were potentially eligible if they assessed symptoms 2-12 weeks after start of therapy. The interventions evaluated were proton pump inhibitors, $\mathrm{H}_{2}$ receptor antagonists, prokinetics, or sucralfate, and these were compared either with each other or with placebo, with or without antacids.

\section{Long term or maintenance trials}

Long term trials were eligible for inclusion if they were randomised controlled trials of maintenance therapy in patients in whom initial therapy had healed reflux oesophagitis. ${ }^{4}$ The same drug therapies as for initial therapy were allowed and patients had to have taken at least 12 weeks of continuous therapy. Symptom assessment had to occur within 12 and 52 weeks.

\section{Statistical analysis}

Data were extracted on symptom scales used, methods of data collection, durations of assessment, whether individual or global symptoms were used, whether reduction or absence of symptoms was the main outcome measure, the types of symptoms assessed, whether frequency and/or severity were evaluated, and whether quality of life and patient satisfaction measures were used. The proportions of patients with a successful outcome according to these different symptom measures were compared with the proportions of patients with healing of oesophagitis, or, in the case of maintenance therapy, the proportion of patients in whom oesophagitis did not relapse. The results are shown in the form of L'Abbé plots $^{5}$ (fig 1), a technique primarily used to explore heterogeneity among trials. In this study, this technique has been used to display graphically the association between the symptom measure and absence of oesophagitis. Each box represents a single intervention within each trial. For example, a trial that evaluated the efficacy of placebo compared to a proton pump inhibitor would generate two boxes on the plot. The size of the box is related to the inverse of the standard error of the proportion healed and, therefore, represents the size of the study. The diagonal line represents the line of equivalence. If a box falls on this equivalence line it suggests that both outcomes were found in the same proportion in each intervention group. If a box is below the line it suggests that the outcome measure being tested against the reference outcome (always plotted on the vertical axis-for example, oesophagitis status) overestimates the treatment effect. Conversely, if boxes appear above the equivalence line, that particular outcome is underestimating the treatment effect compared to the reference outcome-for example, oesophagitis status.

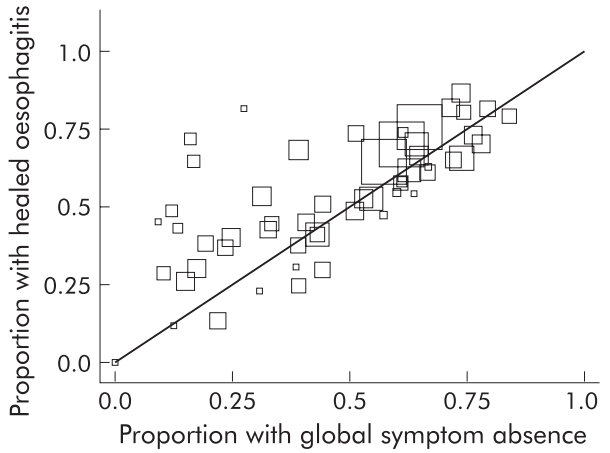

Figure 1 L'Abbé plot of oesophagitis healing and absence of global reflux symptoms.

\section{RESULTS}

\section{Short term trials}

Of 167 trials that were potentially relevant, 126 were eligible. The data were extracted from $108^{6-113}$ papers for this review. Of the trials not included, data required were not extractable from the original texts in eight. The other 10 trials were excluded because they were not published as an English text at the time of writing. The primary symptomatic outcome was explicitly stated in the methods in only $11 / 108(10 \%)$ papers.9 ${ }^{21} 2526496465818588107$ The main outcomes that could be inferred from the papers are given in table 1. Only one paper $^{21}$ used a validated questionnaire as part of the main symptomatic outcome assessment. The most common symptoms to be assessed either individually or as part of a global symptom score were heartburn $(n=93)$, regurgitation $(n=69)$, dysphagia $(n=55)$, and epigastric pain $(n=39)$. Other symptoms assessed included vomiting $(n=22)$, odynophagia $(\mathrm{n}=20)$, nausea $(\mathrm{n}=19)$, and belching $(\mathrm{n}=15)$.

Symptom severity and/or frequency were assessed with a modified Likert scale in 71 of the trials. A 4 point modified Likert scale was most commonly used $(n=53)$ followed by a 5 point scale $(n=12)$, then a 3 point scale $(n=4)$, with 6 and 7 point scales used on only one occasion each. Ordinal scales were used in seven trials and visual analogue scales were used in 12 trials (all used a $100 \mathrm{~mm}$ length scale). Fifty three trials mentioned use of a patient diary card, but investigator interview was also often implied and it was unclear if the reported final outcome related to the patient or the investigator assessment.

Quality of life was formally assessed in six trials, two of which did not use a validated questionnaire. Two trials measured generic quality of life, one with the psychological general well being index (PGWBI) and the other with the short form 36 (SF-36) questionnaire. Patient satisfaction was reported in two trials.

\section{Reduction versus absence of global symptoms as an outcome measure}

Twenty five trials ${ }^{7} 1232333742-4648535557636471899699-102106112$ reported both absence of global symptoms and oesophagitis healing. Authors did not usually define which upper gastrointestinal symptoms were evaluated in their global assessment. Where these were defined, all included heartburn and at least one other upper gastrointestinal symptom (usually regurgitation). Similar proportions of patients had absence of symptoms and healing of oesophagitis according to the L'Abbé plot (fig 1) although there was a trend for absence of global symptoms to underestimate oesophagitis healing when the effect of treatment was small (fig 1). We also identified 13 trials $^{33} 374151556388919496101102105$ that 
Table 1 Main symptomatic outcomes* inferred from the papers included in this systematic review

\begin{tabular}{|c|c|}
\hline Main outcome measure & No of papers \\
\hline Heartburn and regurgitation reported separately & 4 \\
\hline $\begin{array}{l}\text { Heartburn, regurgitation+one other symptom reported } \\
\text { separately }\end{array}$ & 9 \\
\hline $\begin{array}{l}\text { Heartburn, regurgitation+at least two other symptoms } \\
\text { reported separately }\end{array}$ & 18 \\
\hline Heartburn day and night symptoms reported separately & 16 \\
\hline Heartburn frequency and severity reported separately & 1 \\
\hline $\begin{array}{l}\text { Heartburn day, night, frequency and severity reported } \\
\text { separately }\end{array}$ & 5 \\
\hline \multicolumn{2}{|l|}{ Heartburn as sole symptom } \\
\hline Absence & 5 \\
\hline Reduction & 0 \\
\hline Absence and reduction & 12 \\
\hline Change in score & 0 \\
\hline \multicolumn{2}{|l|}{ Global symptoms (symptoms not defined) } \\
\hline Absence & 2 \\
\hline Reduction & 0 \\
\hline Absence and reduction & 6 \\
\hline Change in score & 3 \\
\hline \multicolumn{2}{|l|}{ Global symptoms (heartburn, regurgitation+one other) } \\
\hline Absence & 3 \\
\hline Reduction & 0 \\
\hline Absence and reduction & 1 \\
\hline Change in score & 0 \\
\hline $\begin{array}{l}\text { Global symptoms (heartburn regurgitation+at least two } \\
\text { other symptoms) }\end{array}$ & \\
\hline Absence & 3 \\
\hline Reduction & 2 \\
\hline Absence and reduction & 3 \\
\hline Change in score & 3 \\
\hline \multicolumn{2}{|l|}{ Most marked symptom } \\
\hline Absence & 1 \\
\hline Reduction & 1 \\
\hline Other & 2 \\
\hline Unclear & 8 \\
\hline
\end{tabular}

reported both global symptom reduction and oesophagitis cure. Global symptom reduction overestimated response to treatment compared with oesophagitis healing, as most trials were situated below and to the right of the "equivalence" line of the l'Abbé plot (fig 2). Global symptom absence is, therefore, a better predictor of oesophagitis healing than symptom reduction according to this analysis.

Individual reflux symptoms as outcome measures

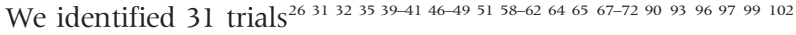
that reported both absence of heartburn and healing of oesophagitis. The proportions of patients with heartburn and oesophagitis healing were very similar across a wide

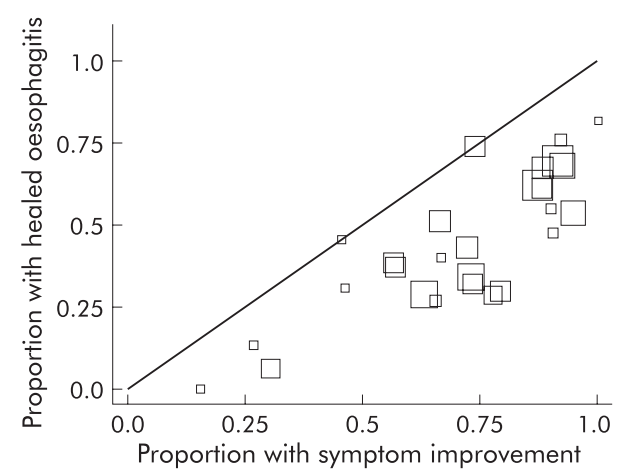

Figure 2 L'Abbé plot of trials reporting symptom reduction and oesophagitis healing. range of treatment effects (fig 3). Absence of regurgitation also showed good correlation with oesophagitis healing in the 20 trials $^{26} 31394046475061646568-729093969799$ that reported the two outcomes (fig 4). There was, however, a tendency for absence of regurgitation to overestimate oesophagitis healing (fig 4), a finding similar to the 20 trials $^{26} 31394046475061646568-729093969799$ in which absence of heartburn could be compared with absence of regurgitation, as the latter tended to slightly overestimate response to treatment (fig 5). There were, however, a few trials in which measures of heartburn overestimated response to treatment compared to regurgitation, so this latter symptom may be useful in some cases (fig 5). Thirteen trials $^{31} 3946476062697072909799102$ evaluated absence of dysphagia and heartburn as outcomes. When absence of dysphagia was used, this overestimated treatment response compared with absence of heartburn (fig 6).

\section{Comparison of frequency and severity of symptoms as outcome measures}

There is a paucity of information on whether either symptom frequency or severity is the best measure of treatment in GORD. We identified two trials ${ }^{35}{ }^{38}$ that reported symptom frequency, symptom severity, and oesophagitis healing. Symptom frequency alone underestimated response to treatment compared with oesophagitis healing (fig 7). Symptom severity gave much closer correlation with oesophagitis healing (fig 8).

\section{Long term trials}

Of the 157 papers that were potentially relevant, 48 were eligible and data could be extracted from 37 of these. $^{821} 106107113-145$ The major cause of ineligibility was that studies enrolled only patients with endoscopy-negative reflux disease. Quality of life outcomes were assessed in three trials, two of which used the PGWBI, and the third used the SF-36 questionnaire. Disease specific quality of life was not measured. Patient satisfaction was recorded in only one trial.

The eligible long term trials were also used to assess the optimum definition of symptom relapse. It is unclear whether symptoms should be assessed over a defined time period. There are also few data on whether relapse should be defined as the presence of any symptom or as the occurrence of moderate or even severe symptoms. We identified seven trials ${ }^{116-122}$ that defined relapse as the presence of any symptom (either heartburn alone or global symptoms); this measure correlated well with the proportion of patients having relapse of oesophagitis (fig 9). All of these trials also defined the period of symptom assessment as between 1-7 days. There were six trials ${ }^{8115}{ }^{122-125}$ that defined relapse as occurrence of moderate to severe symptoms during an

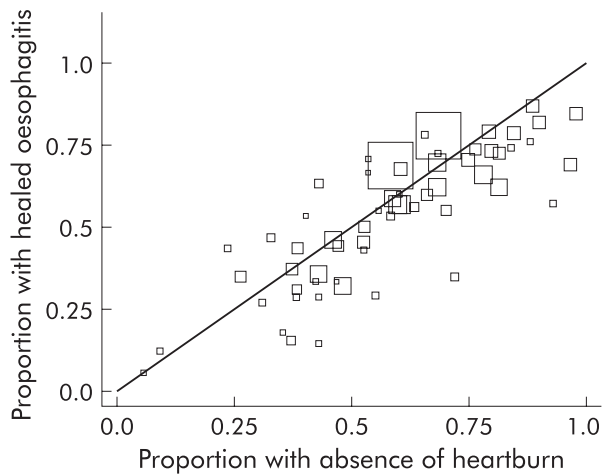

Figure 3 L'Abbé plot of trials reporting oesophagitis and heartburn absence. 


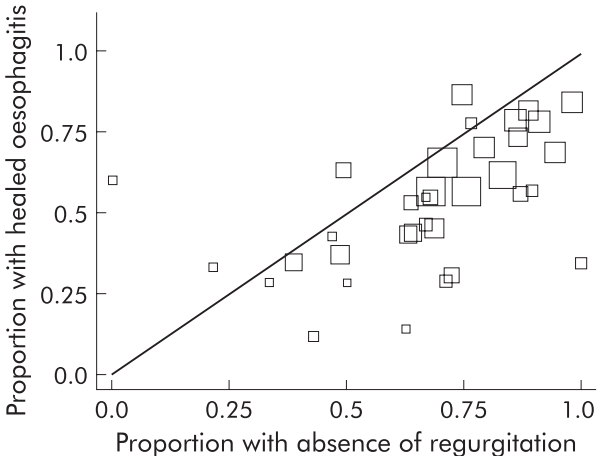

Figure 4 L'Abbé plot of trials reporting oesophagitis healing and absence of regurgitation.

undefined time period. These trials underestimated relapse rates compared with oesophagitis relapse (fig 10). Four trials $^{126-129}$ defined relapse as moderate or severe symptoms over 1-7 days; a similar proportion of patients were in remission using this definition compared with absence of oesophagitis (fig 11).

\section{DISCUSSION}

This is the first review that surveys and assesses the symptom outcome measures and the methodologies used for obtaining symptom data used in randomised controlled trials. This comprehensive, systematically performed overview of the literature has given new insights into the optimal evaluation of symptoms. The methods used in trials to date vary widely. In some instances-most importantly, the number of response options offered to patients-current practices do not reflect what is considered to be best practice. The data suggest that in short term trials, absence of reflux symptoms is a better predictor of healing of oesophagitis than symptom reduction. In long term trials, absence of symptoms also correlates well with remission of oesophagitis, although the time period over which symptoms are evaluated also appears to be important. On the basis of a small number of trials, there also appears to be an additional advantage to measuring severity as well as frequency of reflux symptoms. These data suggest the optimal evaluation would assess symptoms over a set time period and would define treatment success as no more than mild symptoms (for example, reflux symptoms assessed over 1 week with treatment success defined as no more than mild symptoms for 1 day/week).

Clinical trials of GORD drug therapies usually select patients who have predominant heartburn and/or oesophagitis at endoscopy. Patients recruited into trials may,

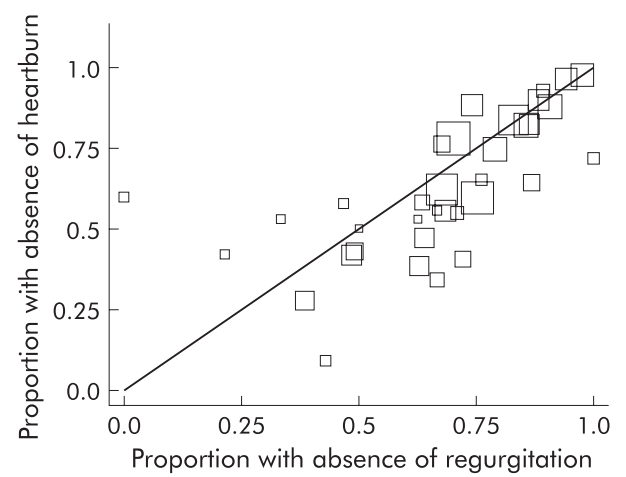

Figure 5 L'Abbé plot of trials reporting heartburn and regurgitation absence.

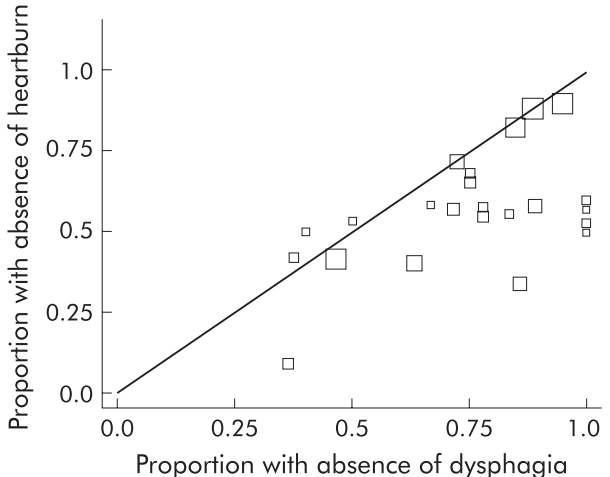

Figure 6 L'Abbé plot of trials reporting heartburn and dysphagia absence.

therefore, have a symptom profile that is not exactly comparable with unselected GORD patients seen in primary care. This must be borne in mind when data from such cohorts are evaluated for the full range of reflux symptoms. With this caveat, heartburn appears to be the most important symptom and, happily, this gives the closest correlation with oesophagitis healing. Absence of heartburn predicts the absence of other reflux symptoms, such as regurgitation and dysphagia, although in a few trials these symptoms were present in patients in whom heartburn was no longer present as a result of therapy. Separate evaluation of regurgitation, and possibly dysphagia, may, therefore, provide additional information. This possibility is supported by our data that suggest that global reflux symptoms also correlate with oesophagitis healing and may be a more conservative measure of treatment success suitable for therapies with low efficacy.

Most studies used a diary card to assess symptoms, which is likely to be the optimal method for gathering information on subjective symptoms (see McColl on page iv49-iv54), ${ }^{147}$ but, frequently, no information was given as to which of these data were being drawn on. When both a diary card and an investigator administered symptom questionnaire are used, authors should clarify which assessment is being reported. Modified Likert scales were nearly always employed to gather information on severity of symptoms; this would also seem the most appropriate method. Importantly, though, the structures of the modified Likert scales used were usually suboptimal, as a 4 point scale was used in the great majority of studies, whereas data suggests a 6 to 7 point scale is more appropriate (see Wyrwich \& Staebler Tardino on page

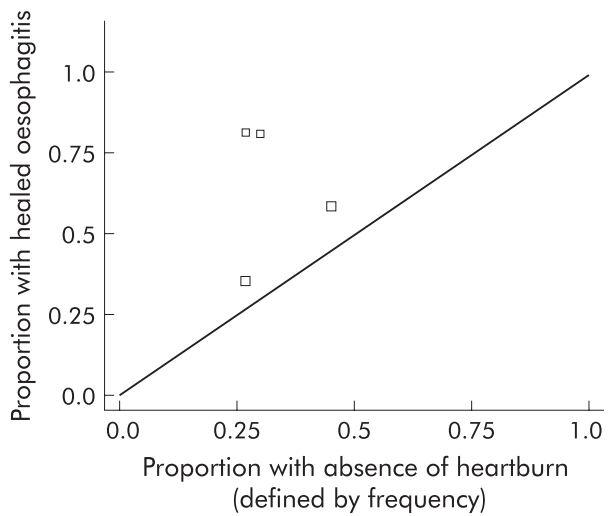

Figure 7 L'Abbé plot of trials reporting symptom frequency and oesophagitis healing. 


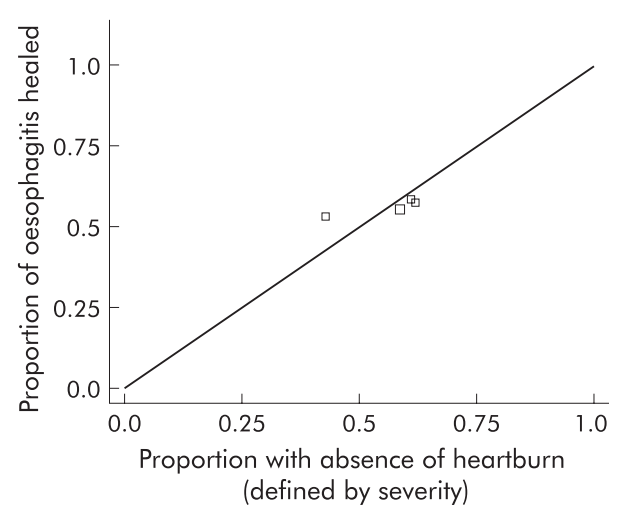

Figure 8 L'Abbé plot of trials reporting heartburn severity and oesophagitis healing.

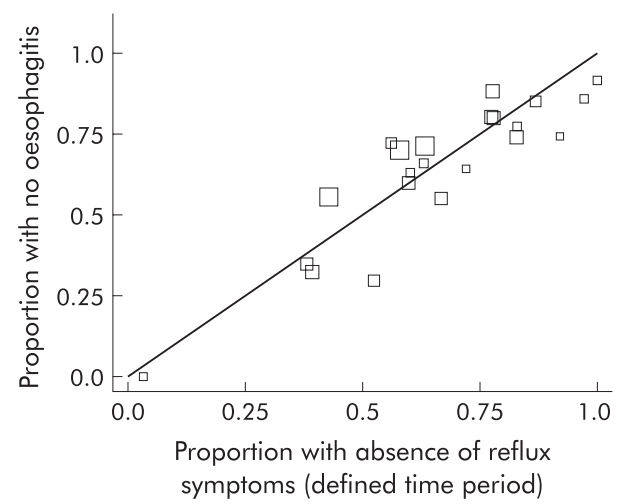

Figure 9 L'Abbé plot of maintenance trials reporting absence of symptoms and prevention of oesophagitis relapse.

iv45-iv48). ${ }^{148}$ Few studies assessed quality of life and even fewer included a measure of patient satisfaction. These outcome measures have major relevance to patients, experience of GORD, and its treatment. Future randomised controlled trials should address these dimensions of disease burden.

Our study findings suggest that the design of trials into reflux disease frequently fails to consider the superiority of patient self report of symptoms, compared with investigator assessment. Greater use of robust, validated self report questions with six to seven response options could significantly enhance the quality of clinical trial data.

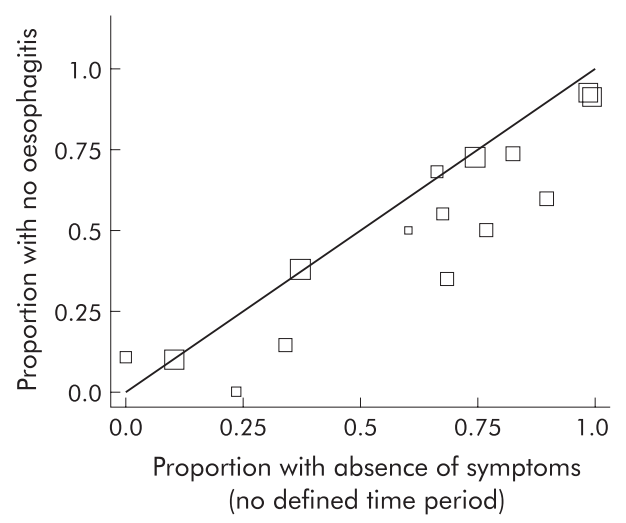

Figure 10 L'Abbé plot of maintenance trials defining moderate/severe symptoms as relapse (with no time period of assessment stated), and prevention of oesophagitis relapse.

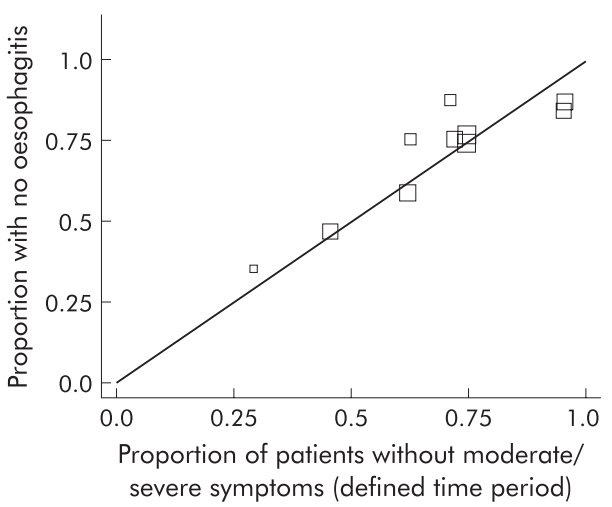

Figure 11 L'Abbé plot of maintenance trials defining moderate/severe symptoms as relapse (over a defined time period) and prevention of oesophagitis relapse.

Some caveats apply to this review of reflux oesophagitis clinical trials. Although we evaluated randomised controlled trials, the randomisation process was not used in the analyses, each treatment arm being considered separately. The information presented is, therefore, observational rather than randomised, controlled data. Outcomes were evaluated in groups of patients rather than individuals, so this ecological analysis could be subject to the ecological fallacy. ${ }^{146}$ For example, if oesophagitis healing is seen in $50 \%$ of patients within a group and absence of heartburn is also seen in $50 \%$, there appears to be perfect agreement between the two outcomes. However, it is possible that the $50 \%$ of cases with oesophagitis healing were all in the patients that continued to have heartburn. This is less of a problem when a successful outcome is found in a high proportion of the group. It can then be assumed we are looking at mostly the same individuals. Furthermore, individual patient data suggest that symptom absence is a good predictor of oesophagitis healing, although there is a $10-20 \%$ discrepancy between the two outcomes. ${ }^{42}$

Healing of oesophagitis was used as the reference standard for success of therapy against which symptom outcomes were compared. This may not be the best outcome to assess, as some patients can remain symptomatic in the absence of erosive oesophagitis. ${ }^{149}$ However, oesophagitis is a very specific marker for GORD, and the most objective outcome measure that is available. This systematic review could not have identified all relevant papers as the searches on which it was based extended only into the year 2000. It is unlikely that inclusion of papers published since then would have any major impact on our conclusions.

Despite its limitations, this systematic review provides a comprehensive summary of the symptom outcome measures that have been used in randomised controlled trials of medical therapy. Our findings suggest that there is considerable potential for reduction and point to how this could be achieved.

\section{Authors' affiliations}

N Sharma, G Duckett, P Moayyedi, Gastroenterology Unit, City Hospital, Dudley Road, Winson Green, Birmingham, UK C Donnellan, C Preston, Centre for Digestive Diseases, The General Infirmary at Leeds, Great George Street, Leeds, UK B Delaney, P Moayyedi, Primary Care Clinical Sciences Building, University of Birmingham, Birmingham, UK

\section{REFERENCES}

1 Armstrong D, Bennett JR, Blum AL, et al. The endoscopic assessment of esophagitis: a progress report on observer agreement. Gastroenterology 1996;111:85-92. 
2 Armstrong D. Endoscopic evaluation of gastro-esophageal reflux disease. Yale J Biol Med 1999;72:93-100.

3 Donnellan C, Preston C, Moayyedi P. Medical treatments for the short term management of reflux oesophagitis (protocol for a Cochrane review). In: The Cochrane Library, Issue 3. Oxford: Update Software, 2002.

4 Preston C, Donnellan C, Moayyedi P. Medical treatments for the maintenance therapy of reflux oesophagitis and endoscopic negative reflux disease (protocol for a Cochrane review). In: The Cochrane Library, Issue 3. Oxford: Update Software, 2002

5 Sharp SJ, Thompson SG, Altman DG. The relation between treatment benefit and underlying risk in meta-analysis. BMJ 1996;313:735-8.

6 Galmiche JP, Barthelemy P, Hamelin B. Treating the symptoms of gastrooesophageal reflux disease: a double-blind comparison of omeprazole and cisapride. Aliment Pharmacol Ther 1997;11:765-73.

7 Johnson NJ, Boyd EJS, Mills JG, et al. Acute treatment of reflux oesophagitis: a multi-centre trial to compare $150 \mathrm{mg}$ ranitidine bd with $300 \mathrm{mg}$ ranitidine gds. Aliment Pharmacol Ther 1989:3:259-66.

8 Sherbaniuk R, Wensel R, Bailey R, et al. Ranitidine in the treatment of symptomatic gastroesophageal reflux disease. J Clin Gastroenterol 1984;6:9-15.

9 Venables TL, Newland RD, Patel AC, et al. Omeprazole $10 \mathrm{mg}$ once daily, omeprazole $20 \mathrm{mg}$ once daily, or ranitidine $150 \mathrm{mg}$ twice daily, evaluated as initial therapy for the relief of symptoms of gastro-oesophageal reflux disease in general practice. Scand J Gastroenterol 1997;32:965-73.

10 Halvorsen $\mathrm{L}$, Lee $\mathrm{FI}$, Wesdorp ICE, et al. Acute treatment of reflux oesophagitis: a multi-centre study to compare $150 \mathrm{mg}$ ranitidine twice daily with $300 \mathrm{mg}$ ranitidine at bedtime. Aliment Pharmacol Ther 1989;3:171-81.

11 Lehtola J, Niemelä S, Martikainen J, et al. Ranitidine, $150 \mathrm{mg}$ three times a day, in the treatment of reflux oesophagitis. A placebo-controlled, doubleblind study. Scand J Gastroenterol 1986;21:175-80.

12 Zeitoun P, Desjars de Keranroué N, et al. Omeprazole versus ranitidine in erosive oesophagitis. Lancet 1987; $2: 621-2$

13 Farup PG, Weberg R, Berstad A, et al. Low-dose antacids versus $400 \mathrm{mg}$ cimetidine twice daily for reflux oesophagitis: a comparative, placebocontrolled, multicentre study. Scand J Gastroenterol 1990;25:315-20

14 Dobrilla G, Chilovi F, Tafner G, et al. Treatment of erosive reflux oesophagitis: a double-blind multicentre trial with nizatidine $300 \mathrm{mg}$ b.i.d versus placebo. Ital J Gastroenterol 1992;24:338-41.

15 Galmiche JP, Brandstätter G, Evreux M, et al. Combined therapy with cisapride and cimetidine in severe reflux oesophagitis: a double blind controlled trial. Gut 1988:29:675-81.

16 Herrera JL, Shay SS, McCabe M, et al. Sucralfate used as adjunctive therapy in patients with severe erosive peptic esophagitis resulting from gastroesophageal reflux. Am J Gastroenterol 1990;85:1335-8.

17 Maleev A, Mendizova A, Popov P, et al. Cisapride and cimetidine in the treatment of erosive esophagitis. Hepatogastroenterology 1990:37:403-7.

18 Festen HPM, Driessen WMM, Lamers CBH, et al. Cimetidine in the treatment of severe ulcerative reflux oesophagitis; results of an 8-week double-blind study and of subsequent long-term maintenance. Neth J Gastroenterol 1980;23:237-40

19 Archambault A, Farley A, Cleator IG, et al. Cimetidine therapy for gastroesophageal reflux disease. West J Med 1985;143:616-21.

20 Janisch HD, Hüttemann W, Bouzo MH. Cisapride versus ranitidine in the treatment of reflux esophagitis. Hepatogastroenterology 1988:35:125-7.

21 Festen HPM, Schenk E, Tan G, et al. Omeprazole versus high-dose ranitidine in mild gastroesophageal reflux disease: short- and long-term treatment Am J Gastroenterol 1999;94:931-5.

22 McKenna CJ, Mills JG, Goodwin C, et al. Combination of ranitidine and cisapride in the treatment of reflux oesophagitis. Eur J Gastroenterol Hepatol 1995; 7:817-22.

23 Bianchi Porro G, Pace F, Sangaletti O, et al. Double-blind clinical study of an alginate compound vs ranitidine in patients with gastroesophageal reflux disease. Adv Ther 1992:9:166-73.

24 Petite JP, Aucomte A, Barbare JC, et al. Lansoprazole versus ranitidine dans la traitement d l'oesophagite peptique par reflux. Etude multicentrique. Med Chir Dig 1991;20:462-7.

25 Green JRB, Tildesley G, Theodossi A, et al. Omeprazole $20 \mathrm{mg}$ to $40 \mathrm{mg}$ once daily is more effective in providing complete symptom relief and endoscopic healing in patients with reflux oesophagitis. $\mathrm{Br} J$ Clin Res 1995:6:63-76.

26 Uleri S, Squassante L, Castelli G. Ranitidine in the treatment of mild to moderate esophageal reflux: a multicentre trial. Curr Ther Res Clin Exp 1993;53:513-20.

27 Hatlebakk JG, Berstad A, Carling L, et al. Lansoprazole versus omeprazole in short-term treatment of reflux oesophagitis. Scand J Gastroenterol 1993;28:224-8.

28 Breen KJ, Desmond PV, Whelan G. Treatment of reflux oesophagitis: a randomised, controlled evaluation of Cimetidine. Med J Aust 1983;2:555-8.

29 Wesdorp ICE, Dekker W, Festen HPM. Efficacy of famotidine $20 \mathrm{mg}$ twice a day versus $40 \mathrm{mg}$ twice a day in the treatment of erosive or ulcerative reflux esophagitis. Dig Dis Sci 1993;38:2287-93.

30 McCarty-Dawson D, Sue SO, Morrill B, et al. Ranitidine versus Cimetidine in the healing of erosive esophagitis. Clin Ther 1996;18:1150-8.

31 Chopra BK, Kazal HL, Mittal PK, et al. A comparison of the clinical efficacy of ranitidine and sucralfate in reflux esophagitis. J Assoc Physicians India 1992;40:439-41.

32 Vantrappen G, Rutgeerts L, Schurmans $P$, et al. Omeprazole $(40 \mathrm{mg})$ is superior to ranitidine in short-term treatment of ulcerative reflux esophagitis. Dig Dis Sci 1988;33:523-9.
33 The Italian Reflux Oesophagitis Study Group. Omeprazole produces significantly greater healing of erosive or ulcerative reflux oesophagitis than ranitidine. Eur J Gastroenterol Hepatol 1991;3:51 1-17.

34 Silver MT, Murdock RH, Morrill BB, et al. Ranitidine $300 \mathrm{mg}$ twice daily and 150 four times daily are effective in healing erosive oesophagitis. Aliment Pharmacol Ther 1996;10:373-80.

35 Farley A, Wruble LD, Humphries TJ. Rabeprazole versus ranitidine for the treatment of erosive gastroesophageal reflux disease: a double-blind, randomised clinical trial. Am J Gastroenterol 2000:95:1894-9.

36 Bate CM, Green JRB, Axon ATR, et al. Omeprazole is more effective than Cimetidine for the relief or all grades of gastroesophageal reflux diseaseassociated heartburn, irrespective of the presence or absence of endoscopic oesophagitis. Aliment Pharmacol Ther 1997;11:755-63.

37 Brown P. Cimetidine in the treatment of reflux oesophagitis. Med J Aust $1979 ; 2: 96-7$

38 Dekkers CPM, Beker JA, Thiodleifsson B, et al. The European Rabeprazole Study Group. Double-blind comparison of rabeprazole $20 \mathrm{mg}$ vs omeprazole $20 \mathrm{mg}$ in the treatment of erosive or ulcerative gastrooesophageal reflux disease. Aliment Pharmacol Ther 1999;11:49-57.

39 Evreux M. Sucralfate versus alginate/antacid in the treatment of peptic esophagitis. Am J Med 1987;83(Suppl 3B):48-50.

40 Van Rensburg CJ, Honiball PJ, Grundling H de K, et al. Efficacy and tolerability of pantoprazole $40 \mathrm{mg}$ versus $80 \mathrm{mg}$ in patients with reflux oesophagitis. Aliment Pharmacol Ther 1996;10:397-401.

41 Klinkenberg-Knol EC, Jansen JMBJ, Festen HPM, et al. Double-blind multicentre comparison of omeprazole and ranitidine in the treatment of reflux oesophagitis. Lancet 1987;1:349-51.

42 Richter JE, Bochenek W. Oral pantoprazole for erosive esophagitis: a placebo-controlled, randomised clinical trial. Pantoprazole US GERD Study Group. Am J Gastroenterol 2000:95:3071-80.

43 Kahrilas PJ, Falk GW, Johnson DA, et al. Esomeprazole improves healing and symptom resolution as compared with omeprazole in reflux oesophagitis patients: a randomised controlled trial. The Esomeprazole Study Investigators. Aliment Pharmacol Ther 2000;14:1249-58.

$44 \mathrm{Van} \mathrm{Zyl} \mathrm{JH}$, Grundling H de K, van Rensburg CJ, et al. Efficacy and tolerability of $20 \mathrm{mg}$ pantoprazole versus $300 \mathrm{mg}$ ranitidine in patients with mild reflux oesophagitis: a randomised, double-blind, parallel and multicentre study. Eur J Gastroenterol Hepatol 2000;12:197-202.

45 Jansen JBMJ, Van Oene JC, the Dutch Lansoprazole Study Group. Standarddose lansoprazole is more effective than high-dose ranitidine in achieving endoscopic healing and symptom relief in patients with moderately severe reflux oesophagitis. Aliment Pharmacol Ther 1999:13:1611-20.

46 Mulder CJ, Dekker W, Gerretson M, on behalf of the Dutch Lansoprazole Study Group. Lansoprazole $30 \mathrm{mg}$ versus omeprazole $40 \mathrm{mg}$ in the treatment of reflux oesophagitis grade II, III and IV a (a Dutch multicentre trial). Eur J Gastroenterol Hepatol 1996;8:1101-6.

47 Dehn TCB, Shepherd HA, Colin-Jones D, et al. Double blind comparison of omeprazole $(40 \mathrm{mg}$ od) versus cimetidine $(400 \mathrm{mg}$ qd) in the treatment of systematic erosive reflux oesophagitis, assessed endoscopically, histologically and by 24 hour pH monitoring. Gut 1990;31:509-13.

48 Armbrecht U, Abucar A, Hameeteman W et al. Treatment of reflux oesophagitis of moderate and severe grade with ranitidine or pantoprazole-comparison of 24-hour intragastric and oesophageal $\mathrm{pH}$. Aliment Pharmacol Ther 1997;11:959-65.

49 Richter JE, Kahrilas PJ, Johanson J, et al. Efficacy and safety of esomeprazole compared with omeprazole in GERD patients with erosive esophagitis: a randomised controlled trial. Am J Gastroenterol 2001;96:656-65.

50 Sontag SJ, Hirschowitz BI, Holt S, et al. Two doses of omeprazole versus placebo in symptomatic erosive esophagitis: the US multicentre study. Gastroenterology 1992;102:109-18.

51 Simon TJ, Berlin RG, Tipping R, et al. Efficacy of twice daily doses of 40 or 20 milligrams famotidine or 150 milligrams ranitidine for treatment of patients with moderate to severe erosive esophagitis. Scand I Gastroenterol 1993;28:375-80

52 Robinson M, Decktor DL, Maton PN, et al. Omeprazole is superior to ranitidine plus metoclopramide in the short-term treatment of erosive esophagitis. Aliment Pharmacol Ther 1993;7:67-73.

53 Bardhan KD, Hawkey CJ, Long RG, et al. Lansoprazole versus ranitidine for the treatment of reflux oesophagitis. Aliment Pharmacol Ther 1995;9:145-51

54 Vcev A, Stimac D, Vceva A, et al. Pantoprazole versus omeprazole in the treatment of reflux esophagitis. Acta Med Croatica 1999;53:79-82.

55 Wesdorp E, Bartelsman J, Pape K, et al. Oral Cimetidine in reflux esophagitis: a double blind controlled trial. Gastroenterology 1978;74:821-3

56 Mee AS, Rowley JL. Rapid symptom relief in reflux oesophagitis: a comparison of lanzoprazole and omeprazole. Aliment Pharmacol Ther 1996;10:757-63

57 Geldof $\mathbf{H}$, Hazelhoff $B$, Otten MH. Two different dose regimens of cisapride in the treatment of reflux oesophagitis: a double-blind comparison with ranitidine. Aliment Pharmacol Ther 1993;7:409-15.

58 Goy J, Maynard JH, McNaughton WM, et al. Ranitidine and placebo in the treatment of reflux oesophagitis: a double-blind randomised trial. Med J Aust 1983:2:558-61.

59 Blum AL, Riecken EO, Dammann HG, et al. Comparison of Omeprazole and ranitidine in the treatment of reflux oesophagitis. N Engl J Med 1986;314:716

60 Bremner CG, Marks IN, Segal I, et al. Reflux esophagitis therapy: sucralfate versus ranitidine in a double blind multicenter trial. Am J Med $1991 ; 91($ Suppl 2A):119S-21S. 
61 Carling L, Cronstedt J, Engqvist A, et al. Sucralfate versus placebo in reflux esophagitis: a double-blind, multicentre study. Scand J Gastroenterol 1988;23:1 $117-24$

62 Di Mario F, Battaglia G, Ferrana M, et al. Sucralfate gel versus ranitidine in the treatment of gastroesophageal reflux disease: a controlled study. Curr Ther Res Clin Exp 1994;55:303-9.

63 Ros E, Toledo-Pimentel V, Bordas $\mathrm{JH}$, et al. Healing of erosive esophagitis with sucralfate and cimetidine: influence of pretreatment lower esophageal sphincter pressure and serum pepsinogen I levels. Am J Med 1991;91:2A:107S-13S.

64 Mössner J, Hölscher AH, Herz R, et al. A double-blind study of pantoprazole and omeprazole in the treatment of reflux oesophagitis: a multicentre trial. Aliment Pharmacol Ther 1995;9:321-6.

65 Corinaldesi A, Valentini M, Belaïche J, et al. Pantoprazole and omeprazole in the treatment of reflux oesophagitis: a European multicentre study. Aliment Pharmacol Ther 1995;9:667-71.

66 Palmer RH, Miller DM, Hedrich DA, et al. Cimetidine QID and BID in rapid heartburn relief and healing of lesions in gastroesophageal reflux disease. Clin Ther 1993;15:994-1001.

67 Mekel RCPM. An international multicentre collaborative trail comparing Cimetidine $800 \mathrm{mg}$ twice daily and $400 \mathrm{mg}$ four times daily in the treatment of reflux esophagitis. Curr Ther Res Clin Exp 1988;44:646-57.

68 Bovero E, Cheli R, Barbara L, et al. Short-term treatment of reflux oesophagitis with ranitidine $300 \mathrm{mg}$ nocte: Italian multicentre study Hepatogastroenterology 1987;34:155-9.

69 Masci E, Testoni PA, Passaretti S, et al. Comparison of ranitidine, domperidone maleate and ranitidine+domperidone maleate in the shortterm treatment of reflux oesophagitis. Drugs Exp Clin Res 1985;10:687-92.

70 Guslandi M, Testoni PA, Passaretti S, et al. Ranitidine versus metoclopramide in the medical treatment of reflux esophagitis. Hepatogastroenterology 1983:30:96-8.

71 Koop H, Scepp W, Dammann HG, et al. Comparative trial of pantoprazole and ranitidine in the treatment of reflux oesophagitis. J Clin Gastroenterol 1995;20:192-5

72 Hameeteman W, Boomgaard MVD, Dekker W, et al. Sucralfate versus cimetidine in reflux esophagitis. J Clin Gastroenterol 1987:9.390-4.

73 Arvanitakis C, Nikopoulis A, Theoharidis A, et al. Cisapride and ranitidine in the treatment of gastro-oesophageal reflux disease-a comparative randomised double-blind trial. Aliment Pharmacol Ther 1993;7:635-41

74 Earnest DI, Dorsch E, Jones J, et al. A placebo-controlled dose-ranging study of lansoprazole in the management of reflux oesophagitis. Am J Gastroenterol 1998;93:238-43.

75 Grove O, Bekker C, Jeppe-Hansen MG, et al. Ranitidine and high-dose antacid in reflux oesophagitis. Scand J Gastroenterol 1985:20:457-61.

76 Richter JE, Long JF. Cisapride for gastroesophageal reflux disease: a placebo-controlled, double-blind study. Am J Gastroenterol 1995;90:423-30.

77 Anand BS, Balakrishnan V, Desai D, et al. Controlled comparison of ranitidine and cimetidine in patients of duodenal ulcer, gastric ulcer and reflux oesophagitis: a multicentre study. Indian J Gastroenterol 1986;5:29-33.

78 Beretta L, Bortoli A, de Barolo G, et al. Nizatidine ( $450 \mathrm{mg} /$ day) versus ranitidine $(450 \mathrm{mg} /$ day) in the treatment of erosive esophagitis: a multicentre clinical trial. Curr Ther Res Clin Exp 1991:49:968-73.

79 Williams RM, Orlando RC, Bozymski EM, et al. Multicentre trial of sucralfate suspension for the treatment of reflux esophagitis. Am J Med 1987;83:61-5.

80 Temple JG, Bradby GVH, O'Connor F, et al. Cimetidine and metoclopramide in gastroesophageal reflux disease. BMJ 1983;286:1863-4.

81 Johansson K-E, Boeryd B, Johansson J, et al. Double-blind crossover study of ranitidine and placebo in gastroesophageal reflux disease. Scand J Gastroenterol 1986;21:769-78.

82 Robertson CS, Evans DF, Ledingham SJ, et al. Cisapride in the treatment of gastro-oesophageal reflux disease. Aliment Pharmacol Ther 1993;7:181-90

83 Palmer RH, Frank WO, Rockhold FW, et al. Cimetidine 800 mg twice daily for healing erosions and ulcers in gastroesophageal reflux disease. J Clin Gastroenterol 1990;12(Suppl 2):S29-34.

84 Nelis G. Ranitidine in the management of gastroesophageal reflux disease. Neth J Med 1985;28:197-200.

85 Sontag SJ, Robinson M, McCallum RW, et al. Ranitidine therapy for gastroesophageal reflux disease: results of a large double-trial. Arch Intern Med 1987;147:1485-91.

86 Robinson M, Sahba B, Avner D, et al. A comparison of lansoprazole and ranitidine in the treatment of erosive oesophagitis. Aliment Pharmacol Ther 1995;9:25-31.

87 Delchier JC, Cohen G, Humphries TJ. Rabeprazole, $20 \mathrm{mg}$ once daily or $10 \mathrm{mg}$ twice daily, is equivalent to omeprazole, $20 \mathrm{mg}$ once daily, in the healing of erosive gastroesophageal reflux disease. Scand J Gastroenterol 2000;35: 1245-50.

88 Sabesin SM, Berlin RG, Humphries TJ, et al. Famotidine relieves symptoms of gastroesophageal reflux disease and heals erosions and ulcerations. USA Merck Gastroesophageal Reflux Study Group. Arch Intern Med 1991; 151:2394-400.

89 Deftmer A, Vogt R, Sielaff $F$, et al. Pantoprazole $20 \mathrm{mg}$ is effective for relief of symptoms and healing of lesions in mild oesophagitis. Aliment Pharmacol Ther 1998;12:865-72.

90 Hine KR, Holmes GKT, Melikian V, et al. Ranitidine in reflux oesophagitis: a double-blind placebo-controlled study. Digestion 1987;29:1 19-23.

91 Vermeijden JR, Tytgat DNJ, Schotborgh RH, et al. Combination therapy of sucralfate and ranitidine compared with sucralfate monotherapy in patients with peptic reflux disease. Scand J Gastroenterol 1992;27:81-4.
92 Fielding JF, Doyle GD. Comparison between ranitidine and cimetidine in the treatment of reflux oesophagitis. Ir Med J 1984;77:356-7.

93 Hetzel DJ, Dent J, Reed WD, et al. Healing and relapse of severe peptic esophagitis after treatment with omeprazole. Gastroenterology 1988;95:903-12

94 Kar P, Gurtoo A, Jain SK, et al. Ranitidine versus placebo: a double-blind trial in the management of reflux oesophagitis. Curr Ther Res Clin Exp 1990:47:731-4

95 Elsborg L, Jørgensen F. Sucralfate versus cimetidine in reflux oesophagitis. Scand J Gastroenterol 1991;26:146-50.

96 Laitinen S, Ståhlberg M, Kairalouma MI, et al. Sucralfate and alginate/ antacid in reflux esophagitis. Scand J Gastroenterol 1985;20:229-32.

97 Dakkak M, Jones BP, Scott MGB, et al. Comparing the efficacy of cisapride and ranitidine in oesophagitis: a double-blind, parallel group study in general practice. Br J Clin Pract 1994;48:10-14.

98 Dent J, Hetzel DJ, Mackinnon MA, et al. Evaluation of omeprazole in reflux oesophagitis. Scand J Gastroenterol Suppl 1989;166:76-82.

99 Simon B, Mueller P. Comparison of the effect of sucralfate and ranitidine in reflux esophagitis. Am J Med 1987;83:43-7

100 Baldi F, Bianchi Porro G, Dobrilla G, et al. Cisapride versus placebo in reflux esophagitis: a multicentre double-blind trial. J Clin Gastroenterol 1988;10:614-18.

101 Sandmark S, Carlsson R, Fausa O, et al. Omeprazole or ranitidine in the treatment of reflux oesophagitis: results of a double-blind, randomised, Scandinavian multicentre study. Scand J Gastroenterol 1988;23:625-32

102 Havelund T, Laursen LS, Skoubo-Kristnesen E, et al. Omeprazole and ranitidine in the treatment of reflux oesophagitis - a double-blind comparative trial. BMJ 1988;296:89-91.

103 Powell-Jackson P, Barkley H, Northfield TC. Effect of cimetidine in symptomatic gastroesophageal reflux. Lancet 1978;2:1068-9.

104 Petite JP, and the Group Multicentrique. Efficacité comparée du lansoprazole et de l'oméprazole dans le traitement delosophagite peptique. Med Chir Dig 1995;24:291-3.

105 Simon TJ, Berenson MM, Berlin RG, et al. Randomized, placebo-controlled comparison of famotidine $20 \mathrm{mg} \mathrm{b.d}$. or $40 \mathrm{mg} \mathrm{b.d}$. in patients with erosive oesophagitis. Aliment Pharmacol Ther 1994;8:71-9.

106 Pace F, Sangaletti O, Bianchi Porro G. Short and long-term effect of two different dosages of ranitidine in the therapy of reflux oesophagitis. Ital J Gastroenterol 1990;22:28-32.

107 Toussaint J, Gossuin A, Deruyterre $M$, et al. Healing and prevention of relapse of reflux oesophagitis by cisapride. Gut 1991;32:1280-5.

108 Gustavsson S, Bergström R, Erwall C, et al. Reflux esophagitis: Assessment of therapy effects and observer variation by video documentation of endoscopy findings. Scand J Gastroenterol 1987;22:585-91.

109 Noritsugu U, Miki K, Hoshino E. Lansoprazole versus famotidine in symptomatic reflux oesophagitis: a randomised multicentre study. J Clin Gastroenterol 1995;20:S17-23.

110 Euler AR, Murdock RH, Wilson TH, et al. Ranitidine is effective therapy for erosive esophagitis. Am J Gastroenterol 1993;88:520-4.

111 Venables CW, Dell D, Eccleston D. A double-blind study of metoclopramide in symptomatic peptic oesophagitis. Postgrad Med J 1973; 49(Suppl 4):73-6.

112 Quik RF, Cooper MJ, Gleeson M, et al. A comparison of two doses of nizatidine versus placebo in the treatment of reflux oesophagitis. Aliment Pharmacol Ther 1990:4:201-11.

113 Kaul B, Peterson H, Erichsen H, et al. Gastroesophageal reflux disease: acute and maintenance treatments with cimetidine. Scand J Gastroenterol 1986;21:139-45.

114 Hatlebakk JG, Johnsson F, Vilien M, et al. The effect of cisapride in maintaining symptomatic remission in patients with gastro-oesophageal reflux disease. Scand J Gastroenterol 1997;32:1100-6.

115 Bate CM, Booth SN, Crowe JP, et al. Omeprazole $10 \mathrm{mg}$ or $20 \mathrm{mg}$ once daily in the prevention of recurrence of reflux oesophagitis. Solo Investigator Group. Gut 1995;36:492-8.

116 Vigneri S, Termini R, Leandro G, et al. A comparison of five maintenance therapies for reflux oesophagitis. N Engl J Med 1995;33:1 106-10.

117 Blum AL, Adami B, Bouzo MH, et al. Effect of cisapride on relapse of esophagitis. A multinational, placebo-controlled trial in patients healed with an antisecretory drug. The Italian Eurocis Trialists. Dig Dis Sci 1993;38:551-60.

118 Hatlebakk JG, Berstad A. Lansoprazole 15 and 30 mg daily in maintaining healing and symptom relief in patients with reflux oesophagitis. Aliment Pharmacol Ther 1997;11:365-72.

119 Houcke P, Goldfain D, Guyot P, et al. Prévention des récidives de I'œsophagite par reflux par le lansoprazole: $30 \mathrm{mg}$ un jour sur deux ou $15 \mathrm{mg}$ tous les jours? Acta Endoscopica 2000;30:243-53.

120 Vakil NB, Shaker R, Johnson DA, et al. The new proton pump inhibitor esomeprazole is effective as a maintenance therapy in GERD patients with healed erosive oesophagitis: a 6-month, randomised, double-blind, placebo controlled study of efficacy and safety. Aliment Pharmacol Ther 2001;15:927-35.

121 Gough AL, Long RG, Cooper BT, et al. Lansoprazole versus ranitidine in the maintenance treatment of reflux oesophagitis. Aliment Pharmacol Ther 1996; 10:529-39

122 Staerk Laursen L, Havelund T, Bondesen S, et al. Omeprazole in the longterm treatment of gastroesophageal reflux disease: a double-blind randomised dose-finding study. Scand J Gastroenterol 1995;30:839-46.

123 Carling L, Axelsson CK, Forssell H, et al. Lansoprazole and omeprazole in the prevention of relapse of reflux oesophagitis: a long-term comparative study. Aliment Pharmacol Ther 1998;12:985-90. 
124 Sontag SJ, Kogut DG, Fleischmann R, et al. Lansoprazole prevents recurrence of erosive reflux disease previously resistant to H2-RA therapy. The Lansoprazole Maintenance Study Group. Am J Gastroenterol 1996;91:1758-65.

125 Sontag SJ, Robinson M, Roufail W, et al. Daily omeprazole surpasses intermittent dosing in preventing relapse of oesophagitis: a US multi-centre double-blind study. Aliment Pharmacol Ther 1997;11:373-80.

126 Hallerbäck B, Unge P, Carling L, et al. Omeprazole or ranitidine in longterm treatment of reflux oesophagitis. The Scandinavian Clinics for United Research Group. Gastroenterology 1994;107:1305-11.

127 Escourrou J, Deprez P, Saggioro A, et al. Maintenance therapy with pantoprazole $20 \mathrm{mg}$ prevents relapse of reflux oesophagitis. Aliment Pharmacol Ther 1999;13:1481-91.

128 Plein $\mathrm{K}$, Hotz J, Wurzer $\mathrm{H}$, et al. Pantoprazole $20 \mathrm{mg}$ is an effective maintenace therapy for patients with gastro-oesophageal reflux disease. Eur J Gastroenterol Hepatol 2000;12:425-32.

129 Simon TJ, Roberts WG, Berlin RG, et al. Acid suppression by famotidine $20 \mathrm{mg}$ twice daily or $40 \mathrm{mg}$ twice daily in preventing relapse of endoscopic recurrence of erosive esophagitis. Clin Ther 1995;17:1147-56.

130 Thiodliefsson B, Beker JA, Dekkers C, et al. Rabeprazole vs omeprazole in preventing relapse of erosive or ulcerative gastroesophageal reflux disease. Dig Dis Sci 2000;45:845-53.

131 Lind T, Havelund T, Lundell L, et al On demand therapy with omeprazole for the long-term management if patients with heartburn without oesophagitisa placebo-controlled randomised trial. Aliment Pharmacol Ther 1999;13:907-14.

132 Venables TL, Newland RD, Patel AC, et al. Maintenance treatment for gastro-esophageal reflux disease: a placebo-controlled evaluation of $10 \mathrm{mg}$ omeprazole once daily in general practice. Scand J Gastroenterol 1997;32:627-32.

133 Lundell L, Backman L, Ekström P, et al. Prevention of relapse of reflux oesophagitis after endoscopic healing: the efficacy and safety of omeprazole compared with ranitidine. Scand J Gastroenterol 1991;26:246-56.

134 Johnson Dam Benjamin SB, Vakil NB, Goldstein JL, et al. Esomeprazole once daily for 6 months is effective therapy for maintaining healed erosive esophagitis and for controlling gastroesophageal reflux disease symptoms: a randomised, double-blind, placebo-controlled study of efficacy and safety. Am J Gastroenterol 2001;91:27-34.

135 Bardhan KD, Cherian P, Vaishnavi A, et al. Erosive esophagitis: outcome of repeated long term maintenance treatment with low dose omeprazole $10 \mathrm{mg}$ or placebo. Gut 1998;43:458-64.
136 Lauritsen K, Deviere J, Bigard MA, et al. Esomeprazole $20 \mathrm{mg}$ and lansoprazole $15 \mathrm{mg}$ in maintaining healed reflux oesophagitis: Metropole study results. Aliment Pharmacol Ther 2003;17:333-41.

137 Birbara C, Breiter J, Perdomo C, et al. for the Rabeprazole Study Group. Rabeprazole for the prevention of recurrent erosive or ulcerative gastroesophageal reflux disease. Eur J Gastroenterol Hepatol 2000; 12:889-97.

138 Tytgat GNJ, Koelz H-R, Vosmaer GDC, et al. Sucralfate maintenance therapy in reflux oesophagitis. Am J Gastroenterol 1995;90:1233-7.

139 Kimmig JM. Treatment and prevention of relapse of mild oesophagitis with omeprazole and cisapride: comparison of two strategies. Aliment Pharmacol Ther 1995:9:281-6.

140 Tytgat GNJ, Anker Hansen OJ, Carling L, et al. Effect of cisapride on relapse of reflux oesophagitis, healed with an antisecretory drug. Scand J Gastroenterol 1992;27:175-83.

141 Dent J, Yeomans ND, Mackinnon $M$, et al. Omeprazole v ranitidine for prevention of relapse in reflux oesophagitis. A controlled double blind trial of their efficacy and safety. Gut 1994;35:590-8.

142 Dent J. Australian Clinical Trials of omeprazole in the management of reflux oesophagitis. Digestion 1990;47:69-71.

143 Caos A, Moskovitz M, Dayal Y, et al. Rabeprazole for the prevention of pathologic and symptomatic relapse of erosive or ulcerative gastroesophageal reflux disease. The Rabeprazole Study Group. Am J Gastroenterol 2000;95:3081-8.

144 MacDougall NI, Watson RGP, Collins JSA, et al. Maintenance therapy with cisapride after healing of erosive oesophagitis: a double-blind placebocontrolled trial. Aliment Pharmacol Ther 1997;11:487-95.

145 Angelini G, Castagnini A, Sgarbi D, et al. Confronto tra omeprazalo e ranitidina nel trattamento a medio termine dell'esofagite peptica. Studio multicentre, prospettico, randomizzato. G Ital End Dig 1993;16:85-9.

146 Piantadosi S, Byar DP, Green SB. The ecological fallacy. Am J Epidemiol 1988; 127:893-904

147 McColl E. Best practice in symptom assessment: a review. Gut 2004;53(Suppl IV):iv49-54.

148 Wyrwich KW, Staebler Tardito VM. A blueprint for symptom scales and responses: measurement and reporting. Gut 2004:53(Suppl IV):iv45-8.

149 Watson RG, Tham TC, Johnston BT, et al. Double blind crossover placebo controlled study of omeprazole in the treatment of patients with reflux symptoms and physiological levels of acid reflux - the "sensitive oesophagus". Gut 1997;40:587-90. 